\title{
The effect of dose rate of 1- $\alpha$-hydroxycholecalciferol on calcium and phosphorus metabolism in sheep
}

\author{
By G. D. BRAITHWAITE \\ National Institute for Research in Dairying, Shinfield, Reading RG2 9AT \\ (Received 28 January I980 - Accepted 2I February 1980)
}

I. A combination of a mineral balance and a radioisotope technique has been used to study the relationship between dose rate of $1-\alpha$-hydroxycholecalciferol $\left(1 \alpha-O H-D_{3}\right)$ and the magnitude and duration of its effect on the various processes of calcium and phosphorus metabolism in adult wether sheep.

2. The rate of absorption of $\mathrm{Ca}$ was markedly increased by treatment and maximum response occurred at the lowest dose rate.

3. Although sheep were already Ca-replete, the extra $\mathrm{Ca}$ absorbed was all retained and increased retention was brought about by a combination of an increase in bone accretion and a decrease in bone resorption. This finding conflicts with the generally-held belief that bone resorption is increased by cholecalciferol treatment.

4. The rates of absorption and retention of $\mathrm{P}$ were increased by $I \alpha-O H-D_{s}$ treatment and maximum response occurred at the lowest dose rate.

5. That $\mathbf{P}$ absorption could be increased by treatment suggests that not all the available dietary $\mathbf{P}$ was absorbed in the control period.

6. Although the loss of endogenous $P$ in the faeces was unaltered by treatment, the secretion of $P$ into the gut was increased, and the increase was directly related to increased serum inorganic $P$ concentration.

7. Nearly all the extra $P$ absorbed was retained and increased retention was achieved by a combination of an increased incorporation into and a decreased loss from the non-exchangeable pools of bone and soft tissues.

8. The time interval taken for absorption rates of $\mathrm{Ca}$ and $\mathrm{P}$ to return to normal after the end of each treatment was related to the dose rate of $\mathrm{I} \alpha-\mathrm{OH}-\mathrm{D}_{\mathbf{3}}$. Although higher dose rates had little effect on the magnitude of response, they did prolong slightly the duration of response.

I- $\alpha$-Hydroxycholecalciferol (I $\alpha-\mathrm{OH}-\mathrm{D}_{3}$ ) a synthetic analogue of I- $\alpha$-25-dihydroxycholecalciferol $\left(\mathrm{I} \alpha, 25(\mathrm{OH})_{2} \mathrm{D}_{3}\right)$ the biologically-active metabolite of vitamin $\mathrm{D}$, has been used with some success to prevent post-parturient hypocalcaemia and reduce the incidence of milk fever in dairy cows (Sansom et al. 1976; Barlet, 1977; Gast et al. 1977; Sachs et al. 1977). Recently its mechanism of action has been clarified in studies with lactating ewes (Braithwaite, 1978). Treatment resulted in a marked increase in the absorption of calcium and in the apparent absorption of phosphorus and as a consequence, the negative mineral retention normally associated with peak lactation (Braithwaite et al. 1969), was prevented.

Studies of serum $\mathrm{Ca}$ and $\mathrm{P}$ concentration in cows treated with different doses of $\mathrm{I} \alpha-\mathrm{OH}-\mathrm{D}_{3}$ suggest that larger doses increase the duration, rather than the magnitude of response (Sansom, I977). The relationship between dose rate of $\mathrm{I} \alpha-\mathrm{OH}-\mathrm{D}_{3}$ and the magnitude and duration of its effect on the various processes of $\mathrm{Ca}$ and $\mathrm{P}$ metabolism has now been studied in the sheep, here used as a model ruminant.

\section{EXPERIMENTAL}

Animals, housing and diet. Eight 2-year-old Suffolk $\times$ Scottish blackface wethers weighing $60-70 \mathrm{~kg}$ were housed in metabolism cages designed for the separate collection of urine and faeces. They were maintained on a diet of hay and concentrates (Table I) and had free access to distilled water.

Experimental procedure. Animals were allowed I month to adapt to the experimental diet. They were then given in random order at monthly intervals each of the following four 
Table I. Composition of the basal diet given daily to wether sheep

\begin{tabular}{lccc}
\multicolumn{1}{c}{ Ingredient* } & $\begin{array}{c}\text { Amount } \\
(\mathrm{g} / \mathrm{kg} \text { body-wt) }\end{array}$ & $\begin{array}{c}\text { Total Ca } \\
(\mathrm{mg} / \mathrm{kg} \text { body-wt) }\end{array}$ & $\begin{array}{c}\text { Total P } \\
(\mathrm{mg} / \mathrm{kg} \text { body-wt) }\end{array}$ \\
Hay & 10 & 45.0 & $18 \cdot 7$ \\
Barley & 5 & 2.8 & 18.3 \\
Bran & 1 & 0.6 & 13.0 \\
Soya-bean meal & 1.5 & 5.4 & 10.5 \\
Dicalcium phosphatet & 0.33 & $66 . \mathrm{I}$ & $51 \cdot 4$ \\
Total & & 119.9 & 111.9
\end{tabular}

- The diet also contained $\beta$ eta vitamin No. 3 a (Cooper Nutrition Products Ltd, Witham, Essex) to supply (/ $\mathrm{kg}$ body-weight) $37.5 \mu \mathrm{g}$ retinol equivalent and $0.775 \mu \mathrm{g}$ cholecalciferol.

+ For the experiment with a high calcium intake, this diet was supplemented with double the amount of dicalcium phosphate.

treatments: $0,0.02,0.05$ or $0.1 \mu \mathrm{g} I \alpha-\mathrm{OH}-\mathrm{D}_{3}$ in propylene glycol/kg body-weight per $\mathrm{d}$ injected intramuscularly for $12 \mathrm{~d}$.

$\mathrm{Ca}$ and $\mathrm{P}$ kinetic studies were carried out during the last $7 \mathrm{~d}$ of each treatment. $\mathrm{A}$ known amount of ${ }^{45} \mathrm{Ca}$ as $\mathrm{CaCl}_{2}$ and ${ }^{32} \mathrm{P}$ as orthophosphate $(2.5$ and $6 \mu \mathrm{Ci} / \mathrm{kg}$ body-weight respectively) in aqueous solution was injected into a jugular vein and samples of blood, urine and faeces were collected as previously described (Braithwaite et al. 1969). At the same time Ca and $\mathrm{P}$ balance measurements were made. Balanse measurements were then continued for a further $2 \mathrm{I} \mathrm{d}$ after the end of each treatment period.

Determination of $\mathrm{Ca}$ and $\mathrm{P}$. The methods used for measurement of the $\mathrm{Ca}$ content of blood, food, urine and faeces have been described previously (Braithwaite et al. 1969). Total $P$ content of urine and ashed samples of food and faeces were determined by the procedure of Fiske \& Subbarow (1925) modified (Technicon Instruments Corporation, 1967) for use with an autoanalyser. Serum inorganic phosphorus $\left(\mathrm{P}_{i}\right)$ was measured by the same procedure after first precipitating the protein with trichloroacetic acid (200 g/l) (Manston, 1966).

Measurement of radioactivity. Radioactivity was measured in a Packard liquid-scintillation spectrometer (Model 2450B) by a dual-label technique with external standardization. Samples of serum ( $\mathrm{I} \mathrm{ml}$ of the TCA-supernatant fraction), urine (I $\mathrm{ml}$ acidified with three drops $2 \mathrm{M}$-hydrochloric acid) and ashed faeces in $\mathrm{HCl}$ ( $\mathrm{I} \mathrm{ml}$ ) were counted in Io $\mathrm{ml}$ Insta-gel scintillator solution (Packard Instruments Co. Inc.).

Kinetic analysis. Kinetic analysis of the Ca results was done by the method of Aubert \& Milhaud (1960) modified for use with sheep (Braithwaite et al. 1969; Braithwaite \& Riazuddin, I97I ; Braithwaite \& Glascock, I976).

A similar method of analysis was also used for the $P$ results. The specific radioactivity of serum $P_{\&}$ was plotted $v$. time on semi-logarithmic co-ordinates and the curve was resolved by standard methods of curve analysis into five exponentials. The integral of the curve, which in effect gives the mean specific radioactivity of the exchangeable pool of $P_{1}$ over the $7 \mathrm{~d}$ period of the experiment, together with the total radioactivity recovered in urine and faeces allows calculation of the endogenous loss of $P$ in urine and faeces (faecal endogenous $P$ ). The rate of $\mathrm{P}$ absorption $\left(V_{a}\right)$ was then obtained from the equation

$$
V_{a}=V_{i}+V_{f}-F \text {, }
$$

where $V_{i}$ is the rate of ingestion of $\mathrm{P}, V_{f}$ is the rate of endogenous loss in faeces and $F$ is the rate of total loss in faeces. This method, with minor modifications, has previously been used by other workers to calculate rates of $P$ absorption and faecal endogenous loss of $P$ in both sheep and cattle (Schroder \& Hansard, 1958; Gueguen, 1963; Preston \& Pfander, 1964; Young, Lofgreen et al. 1966; Symonds, 1969). 
Only $80 \%$ of the total body $P$ is present in the skeleton, compared with $99 \%$ of Ca. The remaining $20 \%$ of $\mathrm{P}$ is present in soft tissues, largely in an organic form and probably nonexchangeable. The rate of accretion of $P$ into bone cannot therefore be calculated in the same way as for $\mathrm{Ca}$ and the equation of Aubert \& Milhaud (I960) which describes the total loss of $\mathrm{P}$ from the exchangeable pool $\left(V_{T}\right)$ has to be modified to include the additional loss of $P$ into soft tissues. Thus:

$$
V_{T}=V_{u}+V_{f}+V_{o}^{+}+V_{S T}
$$

where $V_{u}$ is the rate of excretion in the urine, $V_{0}+$ is the rate of accretion of $P$ into bone and $V_{S T}$ is the rate of incorporation of $\mathrm{P}$ into soft tissues. Although the total loss $\left(V_{T}\right)$ can be calculated in the usual way by the method of Parsons (I968) it is not possible to distinguish between $V_{0}^{+}$and $V_{S T}$ and only a combined value for these two processes can be calculated. It is recognized that this combined value may be subject to error. One problem is that calculations are based on the assumption that no radioactivity returns from the nonexchangeable pools during the period of the experiment. Whilst this is probably true of bone $P$ it may not hold for soft-tissue P. Nevertheless this value may be a useful indicator of changes in bone $\mathbf{P}$ metabolism particularly in comparative studies. This belief is strengthened by the present investigations, in which kinetic studies suggest similar changes in $\mathrm{Ca}$ and $\mathbf{P}$ metabolism in bone as a result of $1 \alpha-\mathrm{OH}-\mathrm{D}_{3}$ treatment.

\section{RESULTS AND DISCUSSION}

The $\mathrm{I} \alpha-\mathrm{OH}-\mathrm{D}_{3}$ treatment resulted in a marked increase in the rates of absorption and retention of $\mathrm{Ca}$ (Table 2). There was no significant difference, however, due to the level of dose given, maximum response occurring at the lowest dose rate. Since the efficiency of absorption of $\mathrm{Ca}$ during treatment approached $50 \%$ which is probably the maximum obtainable from hay and concentrate diets (Braithwaite, 1976), absorption may have been limited by the availability of dietary $\mathrm{Ca}$. To eliminate this possibility, these same sheep, treated with the highest dose rate of $\left[\alpha-\mathrm{OH}-\mathrm{D}_{3}\right.$ were given a Ca intake of $200 \mathrm{mg} / \mathrm{d}$ per $\mathrm{kg}$ body-weight, i.e. nearly double the previous intake. The resulting rates of absorption and retention of $\mathrm{Ca}$ were virtually identical with those obtained at the lower intake. The limiting factor in absorption therefore could not have been availability of dietary Ca but must rather have been the capacity of the intestine to absorb $\mathrm{Ca}$, which presumably became saturated even at the lowest dose rate of $\mathrm{I} \alpha-\mathrm{OH}-\mathrm{D}_{3}$ used.

Nearly all the extra $\mathrm{Ca}$ absorbed during treatment was retained. Faecal endogenous loss of $\mathrm{Ca}$ was unchanged and loss in urine increased only slightly at the higher dose rates. Since these sheep were already $\mathrm{Ca}$-replete and in the control period absorbed only enough to meet their maintenance requirements (i.e. unavoidable losses in urine and into intestine), it is surprising that the extra $\mathrm{Ca}$ absorbed during treatment was retained and not immediately excreted. These findings, however, do support a previous suggestion (Braithwaite, 1979) that ruminants may lack a mechanism for eliminating surplus $\mathrm{Ca}$.

The increased total body retention of $\mathrm{Ca}$, which reflected an increase in skeletal retention, was brought about by a combination of a decrease in the rate of bone resorption and an increase in the rate of bone accretion. This finding disagrees with the generally-held belief that the major effect of $1 \alpha, 25(\mathrm{OH})_{2} \mathrm{D}_{3}$ on bone is to increase bone resorption (Fraser \& Kodicek, 1973; Deluca, 1975, 1977). However, evidence is now accumulating which throws doubt on this belief and which instead suggests that the predominant effect of $1 \alpha, 25(\mathrm{OH})_{2} \mathrm{D}_{3}$ is to increase bone accretion. Thus, increased bone accretion rates have been reported in man and in lactating ewes treated with $1 \alpha-O H-D_{3}$ (Pierides et al. 1976; Braithwaite, 1978) and in mature rats treated with $\mathrm{I} \alpha, 25,(\mathrm{OH})_{2} \mathrm{D}_{3}$ (Larsson et al. 1977). Furthermore, it must be pointed out that the $\mathrm{I} \alpha-\mathrm{OH}-\mathrm{D}_{3}$ and $\mathrm{I} \alpha, 25(\mathrm{OH})_{2} \mathrm{D}_{3}$ mediated 


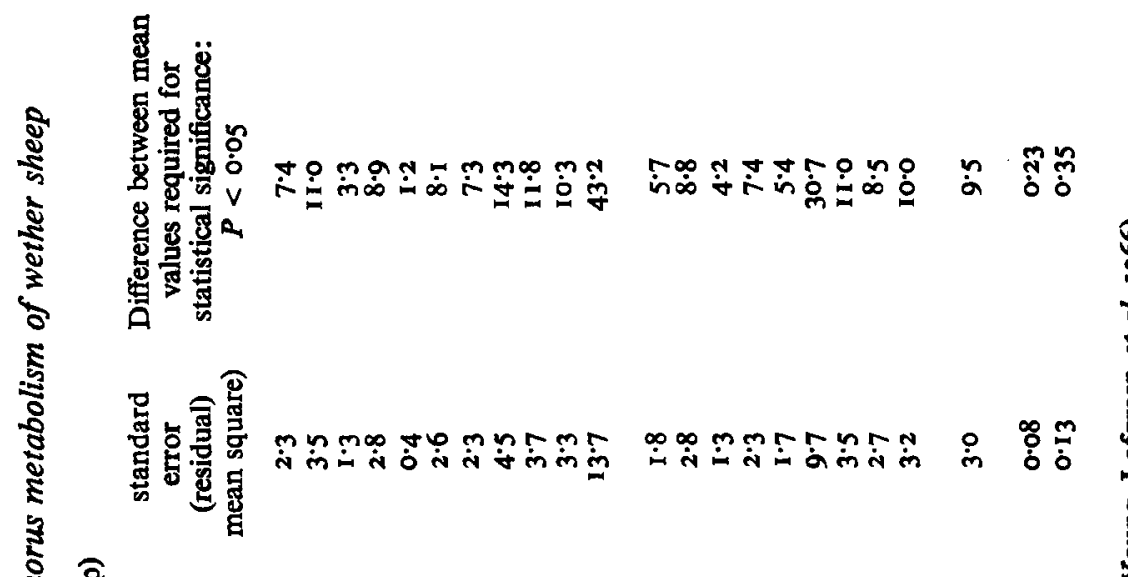


increase in bone resorption was demonstrated in vivo only in animals maintained on Cadeficient diets (Tanaka \& DeLuca, I97I ; Wong et al. 1972; Holick et al. 1976). The present results suggest that such an increase is unlikely to occur in mature animals maintained on adequate $\mathrm{Ca}$ intakes. In any case, it is difficult to understand how both $\mathrm{Ca}$ absorption and bone resorption could increase at the same time without either a concomitant increase in the rate of loss or a continuously-expanding pool of exchangeable $\mathrm{Ca}$. In the present experiments, the loss of $\mathrm{Ca}$ increased only slightly and neither the rapidly-exchangeable $\mathrm{Ca}$ pool of soft tissues nor the slowly-exchangeable $\mathrm{Ca}$ pool of bone were altered by treatment. Serum $\mathrm{Ca}$ concentration, however, did increase slightly at the higher dose rates.

Results of the $\mathbf{P}$ kinetic studies are also shown in Table 2. The rates of absorption and retention of $\mathrm{P}$, like those of $\mathrm{Ca}$, were increased by the $\mathrm{I} \alpha-\mathrm{OH}-\mathrm{D}_{3}$ treatment but again there was no direct relationship between magnitude of response and dose rate, maximum response occurring at the lowest dose.

In experiments with lactating ewes, it was found that $1 \alpha-\mathrm{OH}-\mathrm{D}_{3}$ treatment increased the apparent absorption of $\mathrm{P}$ (Braithwaite, 1978) but it was not possible to decide whether this increase was due to an increase in true absorption or to a decrease in endogenous secretion. These results now show that the major effect of $\mathrm{I} \alpha-\mathrm{OH}-\mathrm{D}_{3}$ treatment was to stimulate $\mathrm{P}$ absorption, though faecal endogenous excretion did decrease slightly at the higher dose rates.

The increase in $\mathbf{P}$ absorption during treatment suggests that not all the available dietary $\mathbf{P}$ was absorbed in the control period. A failure to absorb all the available dietary $\mathbf{P}$ was also suggested in animals given the higher $\mathrm{Ca}$ intake. Although $\mathrm{P}$ intake was also increased, no further increase in $\mathbf{P}$ absorption occurred and as a consequence the efficiency of absorption was decreased. These findings are of particular interest in view of previous studies (Lueker \& Lofgreen, I961; Preston \& Pfander, 1964; Young, Richards et al. 1966), which show that $\mathbf{P}$ is absorbed in direct relation to intake, and suggest that absorption is normally limited by the availability of dietary $P$. Of course, the possibility exists that in the presence of large amounts of dietary $\mathrm{Ca}$, much of the dietary $\mathrm{P}$ is precipitated in the intestine as insolublecalcium phosphate and is unavailable for absorption. During I $\alpha-\mathrm{OH}-\mathrm{D}_{3}$ treatment, the increased $\mathrm{Ca}$ absorption may then result in less precipitation of $\mathrm{P}$ and hence more being available for absorption.

A large number of studies in various species have now shown that $P$ absorption is increased by vitamin $D$ and its metabolites (Harrison \& Harrison, I96I; Wasserman \& Taylor, 1973; Chen et al. 1974; Fox \& Care, 1976). There is controversy, however, over the actual mechanism by which this increase is achieved (Wasserman, 1975; Norman, 1978). For example, it is not yet firmly established whether it occurs as a result of a direct stimulation by $\mathrm{I} \alpha, 25(\mathrm{OH})_{2} \mathrm{D}_{3}$, or whether $\mathrm{P}$ is absorbed as a co-ion with $\mathrm{Ca}$. Certainly in the present experiments the ratio, $\mathrm{Ca}: \mathrm{P}$ absorbed as a result of $\mathrm{I} \alpha-\mathrm{OH}-\mathrm{D}_{3}$ treatment, i.e.

$$
\frac{\mathrm{Ca}_{a} \text { (treated) }-\mathrm{Ca}_{a} \text { (control) }}{\mathbf{P}_{a} \text { (treated) }-\mathbf{P}_{a} \text { (control) }},
$$

remained remarkably constant at approximately $\mathrm{I} \cdot 6: \mathrm{I}$, irrespective of dose rate, which might be regarded as evidence of a coupled $\mathrm{Ca}: \mathrm{P}$ absorption. However, further investigations of $\mathrm{P}$ metabolism in $\mathrm{I} \alpha-\mathrm{OH}-\mathrm{D}_{3}$-treated sheep given high or low $\mathrm{Ca}$ intakes now suggest that the increase in $\mathrm{P}$ absorption is independent of $\mathrm{Ca}$ absorption (Braithwaite, unpublished results).

The slight decrease in endogenous loss of $P$ in the faeces during treatment is surprising in view of the increased serum $P_{i}$ concentration. At first sight this seems to suggest that endogenous secretion is not related to serum $P_{i}$ concentration. However, if the total rate of 


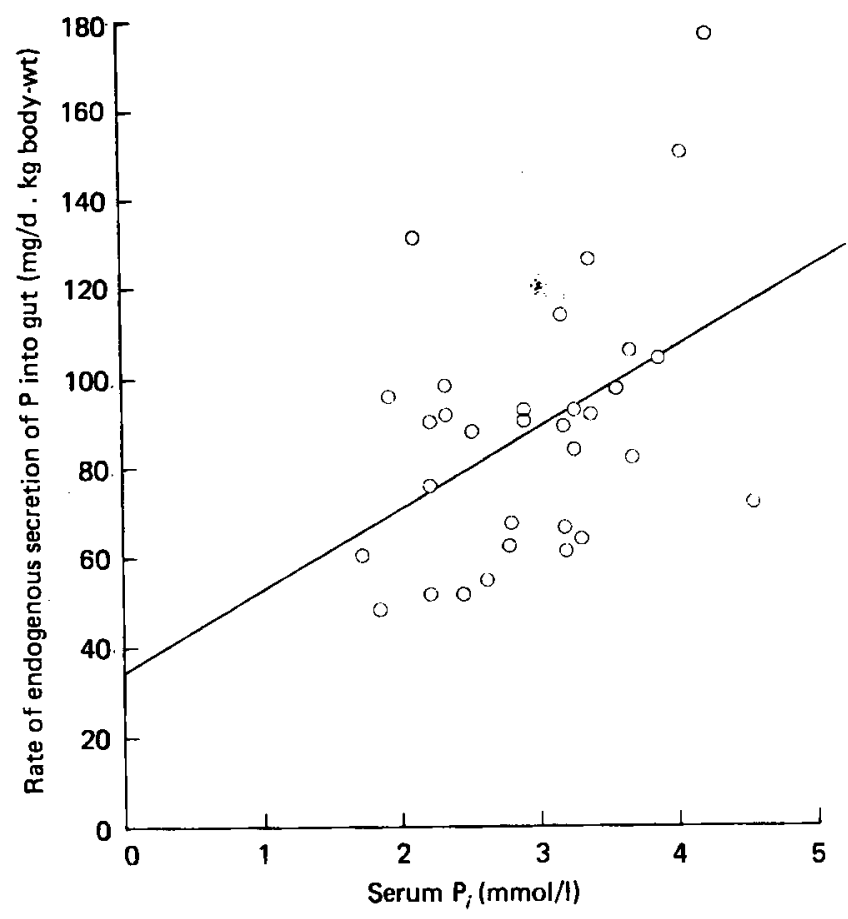

Fig. I. Relationship between serum inorganic phosphorus $\left(\mathbf{P}_{i}\right)(\mathrm{mmol} / \mathrm{l})$ and the rate of endogenous secretion of $P\left(\mathrm{mg} / \mathrm{d}\right.$ per $\mathrm{kg}$ body-weight) into the gut $\left(P_{8}\right)$ of wether sheep. $P_{d}=34.5+18 P_{b}$; ro.45.

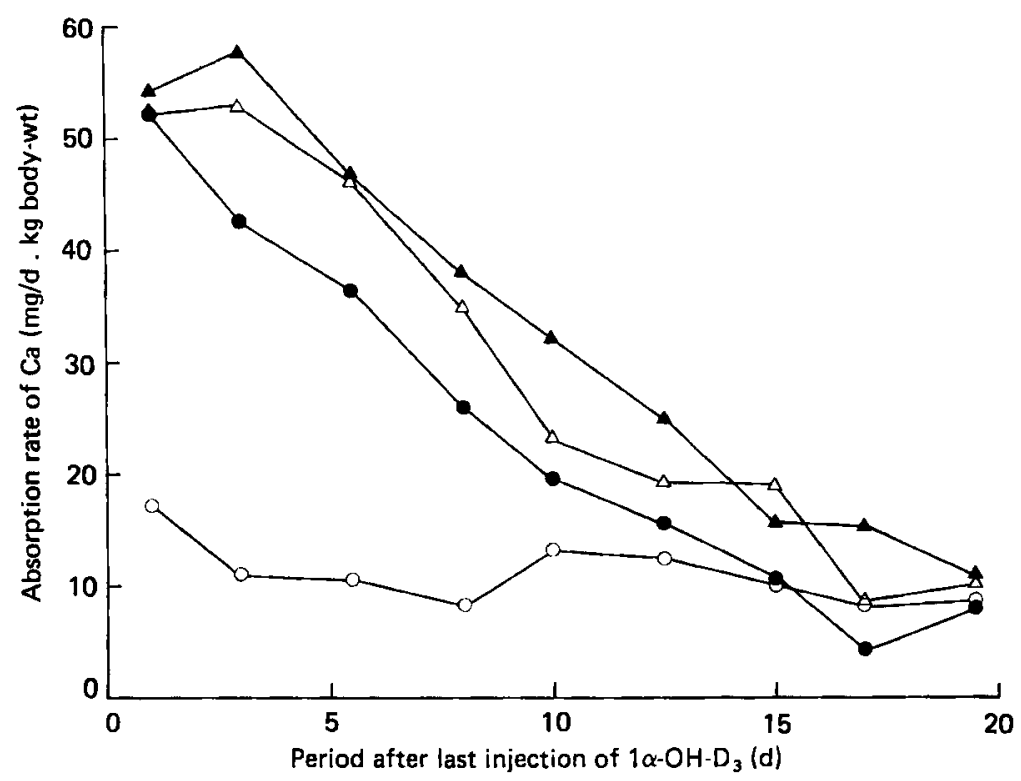

Fig. 2. Changes in the rate of absorption of $\mathrm{Ca}(\mathrm{mg} / \mathrm{d}$ per $\mathrm{kg}$ body-weight) in wether sheep during the $21 \mathrm{~d}$ immediately after the end of the $1 \alpha$-hydroxycholecalciferol $\left(\mathrm{I} \alpha-\mathrm{OH}-\mathrm{D}_{\mathrm{\jmath}}\right)$ treatment periods. 0 , Control; $0,0.02 ; \Delta, 0.05 ; \Delta, 0.1 \mu \mathrm{g} 1 \alpha-\mathrm{OH}-\mathrm{D}_{\mathbf{3}} / \mathrm{d}$ per $\mathrm{kg}$ body-weight. 


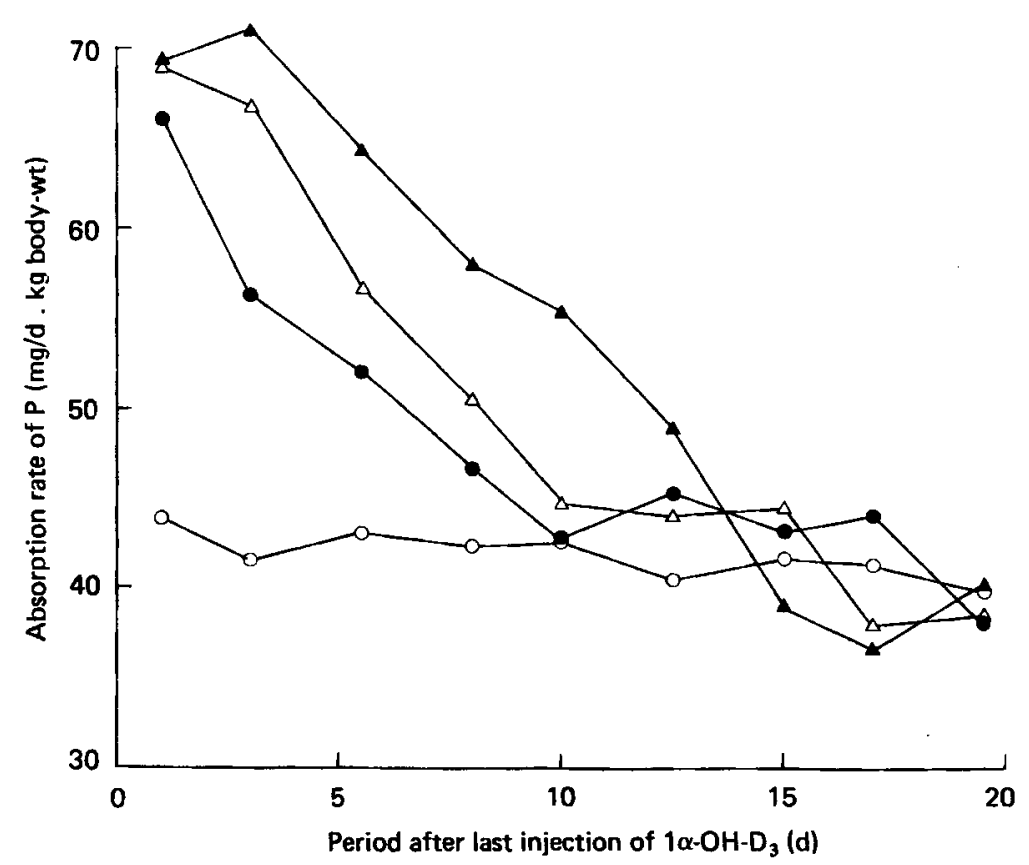

Fig. 3. Changes in the rate of absorption of $P(\mathrm{mg} / \mathrm{d}$ per $\mathrm{kg}$ body-weight) in wether sheep during the $21 \mathrm{~d}$ immediately after the end of the $1 \alpha$-hydroxycholecalciferol (I $\alpha-\mathrm{OH}-\mathrm{D}_{2}$ ) treatment periods. $O$, Control; $0,0.02 ; \Delta, 0.05 ; \Delta, 0.1 \mu \mathrm{g}$ I $\alpha-O H-D_{3} / \mathrm{d}$ per $\mathrm{kg}$ body-weight.

Table 3. Total absorption of calcium and phosphorus ( $\mathrm{mg} / \mathrm{kg}$ body-weight) during the $2 \mathrm{I} d$ immediately after the end of $1-\alpha$-hydroxycholecalciferol treatment

(Results are the mean of eight animals/group)

$\begin{array}{lcrrrc} & 1 \alpha-\mathrm{OH}-\mathrm{D}_{2}(\mu \mathrm{g} / \mathrm{d} \text { per kg body-wt) } & \begin{array}{c}\text { Standard error } \\ \text { of difference } \\ \text { (2I df) }\end{array} \\ \text { Total Ca absorption } & 0 & 0.02 & 0.05 & 0.1 & 31 \cdot 1 \\ \text { Total P absorption } & 238 & 490 & 608 & 669 & 65.7\end{array}$

secretion of $\mathbf{P}$ into the upper small intestine is calculated by the formula of Young, Lofgreen et al. (1966):

$$
\text { rate of endogenous secretion }=\frac{\text { rate of endogenous loss in faeces }}{\mathrm{I}-\text { fraction of dietary } \mathrm{P} \text { absorbed }}
$$

which is based on the assumption that endogenous $P$ is reabsorbed with the same efficiency as dietary $P$, then it is clear that total endogenous secretion was increased by $1 \alpha-O H-D_{3}$ and was related $(P>0 \cdot 0 I)$ to serum $P_{i}$ concentration (Fig. I).

Nearly all the additional $P$ absorbed during treatment was retained and the increased retention was achieved by a combination of an increased incorporation into the nonexchangeable pools of bone and soft tissues and a decreased loss from these pools. Although it was not possible to distinguish between the bone and the soft tissue $P$, changes in the rates of incorporation of $\mathbf{P}$ into and loss from the combined pool as a result of treatment did follow the same trend as changes in the rates of $\mathrm{Ca}$ accretion into and resorption from bone.

Recent work has suggested that it is not the magnitude of response that is altered by increased dose rates of $\mathrm{I} \alpha-\mathrm{OH}-\mathrm{D}_{3}$ but rather the duration of response (Sansom, I977). 
Figs. 2 and 3 show the mean absorption rates of $\mathrm{Ca}$ and $\mathrm{P}$ respectively for the four treatments, calculated from balance measurements carried out during the $2 \mathrm{I} d$ period immediately after the end of the $\mathrm{I} \alpha-\mathrm{OH}-\mathrm{D}_{3}$ administration. In these calculations, it was assumed that the faceal endogenous loss of $\mathrm{Ca}$ and $\mathrm{P}$ remained constant and equal to the mean values obtained in the control period.

The absorption rate of $\mathrm{Ca}$ was initially maintained at a high level, but then fell steadily, the time taken to return to normal being related to the dose rate of $1 \alpha-O H-D_{3}$. Total absorption of $\mathrm{Ca}$ over the whole $2 \mathrm{I} d$ period was markedly increased by treatment $(P<$ 0.001 , Table 3), the greatest increase occurring at the highest dose rate.

The pattern of changes in absorption rates of $\mathrm{P}$ was similar to that for $\mathrm{Ca}$, except that the rates returned to normal levels earlier. Consequently, the increase with increasing dose levels, in total absorption over the 2 I d period, while still significant $(P<0.05)$ was less than for Ca.

These results confirm that the main effect of $\mathrm{I} \alpha-\mathrm{OH}-\mathrm{D}_{3}$ is to increase $\mathrm{Ca}$ and $\mathrm{P}$ absorption. They also show that increased dose rates above $0.02 \mu \mathrm{g} / \mathrm{d}$ per $\mathrm{kg}$ body-weight have little effect on the magnitude of response but do prolong slightly the duration of response. There may therefore be little advantage in using doses greater than $0.02 \mu \mathrm{g} / \mathrm{d}$ for preventing deficiency disorders and possibly even lower doses may be just as beneficial.

I thank Miss F. J. McEwan and Mr R. J. Ranson for skilled technical assistance, Mr A. Mowlem for supervising the care of the experimental animals and $\mathrm{Mr}$ J. M. Pott of Leo Laboratories for the supply of $\mathrm{I} \alpha-\mathrm{OH}-\mathrm{D}_{3}$.

\section{REFERENCES}

Aubert, J.-P. \& Milhaud, G. (1960). Biochim. biophys. Acta 39, 122.

Barlet, J.-P. (1977). Annls Biol. Anim. Biochim. Biophys. 17, 363.

Braithwaite, G. D. (1976). J. Dairy Res. 43, 501.

Braithwaite, G. D. (1978). Br. J. Nutr. 40, 387.

Braithwaite, G. D. (1979). J. agric. Sci., Camb. 92, 337.

Braithwaite, G. D. \& Glascock, R. F, (1976). Bienn. Rev. natn. Inst. Res. Dairy.

Braithwaite, G. D., Glascock, R. F. \& Riazuddin, Sh. (1969). Br. J. Nutr. 23, 827.

Braithwaite, G. D. \& Riazuddin, Sh. (197I). Br. J. Nutr. 26, 215.

Chen, T. C., Castillo, L., Korycka-Dahl, M. \& DeLuca, H. F. (1974). J. Nutr. 98, 1056.

DeLuca, H. F. (1975). Acta orthop. scand. 46, 286.

DeLuca, H. F. (1977). Adv. clin. Chem. I9, 125.

Fiske, C. H. \& Subbarow, Y. (I925). J. biol. Chem. 66, 375.

Fox, J. \& Care, A. D. (1976). In Calcified Tissues '1975', p. I47 [S. Pors Nielson \& Hjorting-Hanson, editors]. Copenhagen: FADL Publishing Co.

Fraser, D. R. \& Kodicek, E. (1973). Nature, New Biol. 241, I63.

Gast, D. R., Marquardt, J. P., Jorgensen, N. A. \& DeLuca, H. F. (r977). J. Dairy Sci. 60, 1910.

Gueguen, L. (I963). Annls Biol. Anim. Biochim. Biophys. 3, 243.

Harrison, H. E., \& Harrison, H. C. (1961). Am. J. Physiol. 201, 1007.

Holick, M. F., Taleva, T. E., Holick, S. A., Schnoes, H. K., DeLuca, H. F. \& Gallagher, B. M. (I976). I. biol. Chem. 251, 1020.

Larsson, S.-E., Lorentzon, R. \& Boquist, L. (1977). Clin. Orthop. Relat. Res. 127, 228.

Lueker, C. E. \& Lofgreen, G. P. (1961). J. Nutr. 74, 233.

Manston, R. (1966). Br. vet. J. 122, 443 .

Norman, A. W. (1978). In Vitamin D, ch. 3, [D. E. M. Lawson, editor]. New York and London: Academic Press.

Parsons, D. H. (1968). Mathl. Biosci. 2, 191.

Pierides, A. M., Simpson, W., Ward, M. K., Ellis, H. A., Dewar, J. H. \& Kerr, D. N. S. (1976). Lancet i, I092.

Preston, R. L. \& Pfander, W. H. (1964). J. Nutr. 83, 369.

Sachs, M., Bar, A., Cohen, R., Mazur, Y., Mayer, E. \& Hurwitz, S. (1977). Am. J. vet. Res. 38, 2039.

Sansom, B. F. (1977). Vet. Sci, Commun. I, 323. 
Sansom, B. F., Allen, W. M., Davies, D. C., Hoare, M. N., Stenton, J. R. \& Vagg, M. J. (1976). Vet. Rec. 99, 310.

Shroder, J. D. \& Hansard, S. L. (1958). J. Anim. Sci. 17, 343.

Symonds, H. W. (1969). Res. vet. Sci. 10, 584.

Tanaka, Y. \& DeLuca, H. F. (197I). Archs Biochem. Biophys. 146, 574.

Technicon Instruments Corporation (1967). Technicon Method Sheet N-4B. Tarry Town, New York: Technicon Instruments Corporation.

Wasserman, R. H. (1975). Cornell Vet. 65, 3.

Wasserman, R. H. \& Taylor, A. N. (1973). J. Nutr. 103, 586.

Wong, R. G., Myrtle, J. F., Tsai, H. C. \& Norman, A. W. (1972). J. biol. Chem. 247, 5728.

Young, V. R., Lofgreen, G. P. \& Luick, J. R. (1966). Br. J. Nutr. 20, 795.

Young, V. R., Richards, W. P. C., Lofgreen, G. P. \& Luick, J. R. (1966). Br. J. Nutr. 20, 783. 